\title{
Tales of the Phylogenetic Woods: The Evolution and Significance of Evolutionary Trees
}

\author{
C. LORING BRACE \\ Museum of Anthropology, University of Michigan, Ann Arbor, Michigan \\ 48109
}

\section{KEY WORDS Classification, Phylogeny, Trees}

\begin{abstract}
The styles of continuing intellectual traditions can have a major effect on the way in which scientific findings are expressed. Darwin and Huxley, for all their intellectual daring followed the skeptical tactics of the Scottish Enlightenment and avoided the construction of human phylogenetic trees, even though they were aware of the evidence on which such could have been constructed. The romantic evolutionism of Haeckel, Keith, and many subsequent writers in English produced suggested phylogenies on the basis of largely hypothetical forms including Homo "alalus," "stupidus," and "Eoanthropus." The structural aspects of phylogenetic schemes that derive from the French intellectual ethos, from catastrophism to cladistics and punctuated equilibria, have stressed discrete categorical entities in the tradition of Platonic essentialism and have tended to avoid a consideration of evolutionary dynamics.
\end{abstract}

Intellectual traditions frequently shape the way in which scientific questions are posed as well as the procedures undertaken to answer them. When I attempted to provide a paleoanthropological illustration of this realization some 15 years ago (Brace, 1964), one of the commentators phrased the rhetorical query, "Since when in science can one base oneself on arguments of nationality?" (Genovés, 1964:23). This objection was raised in regard to issues relating to the phylogenetic treatment of a particular set of human fossils, and, from the perspective of the history of science, a relatively minor matter. The proper response, had I been adequately prepared, would have been to note the reaction of a figure of unimpeachable stature to the various ways in which a truly major scientific synthesis was perceived. The best example is the reaction of none other than Charles Darwin to the reception of his theory of evolution by means of natural selection. In a letter he wrote to the French anthropologist Armand de Quatrefages, he said, "It is curious how nationality influences opinion; a week hardly passes without my hearing of some naturalist in Germany who supports my views, and often puts an exaggerated value on my works; whilst in France I have not heard of a single zoologist, except M. Gaudry (and he only partially) who supports my views" (in F. Darwin [ed.], 1887:299).
The Comparative Reception of Darwinism (Glick [ed.], 1974) admirably documents the fact that there are indeed different national styles of thinking when it comes to dealing with major aspects of science. If this has been true for the treatment of the interpretation of organic evolution in general, it has also been true for approaches to the study of human evolution in particular. As this paper will at tempt to show, this is graphically illustrated by the various forms that are offered as human phylogenetic trees.

\section{NINETEENTH CENTURY ENGLAND}

Verbal portrayals of human descent in the form of a tree are present in the very earliest written records and are commonly found in cultures that lack a system of writing. Further, many cultures contain accounts of the kinship between humans and particular members of the animal kingdom, although these are usually expressed in symbolic and totemic form and rarely, if ever, rendered as identifiable parts of a literal family tree (cf. treatments by Frazer, 1887; Freud, 1950; Lévi-Strauss, 1962). While there were occasional earlier attempts to portray a more than biblical human antiquity and a putative lineal kinship with nonhuman an-

Delivered at the University of Virginia, Charlottesville, December 11-12, 1980 
cestors (see the treatments in Eiseley, 1958; Greene, 1959; Osborn, 1894), it is clear from the record that a systematic concern for the course and forms of human ancestral development did not begin until after the publication in 1859 of that extraordinary scientific landmark, On the Origin of Species, by Charles Darwin.

To be sure, despite popular assumptions to the contrary (Wilberforce, 1860:135; Broca, 1862:314), Darwin only alluded to the possibility that his approach could be applied toward an analysis of the human condition barely more than two paragraphs from the end of his epoch-making work when he wrote, "Light will be thrown on the origin of man and his history" (1859:488). In subsequent editions, this was expanded only to the extent that he said "Much light will be thrown. ..." (cf. 1872:504).

If this seems in retrospect to be brief to the point of being cryptic, the implications were not lost on Darwin's contemporaries despite the fact that he himself waited a dozen years before developing the theme in The Descent of Man (1871). While Darwin proceeded with deliberate caution, others were quicker to follow the path to which he had pointed. Nor did these accounts display signs of unseemly haste. The evidence for human antiquity presented by Sir Charles Lyell (1863) was the product of several decades of meticulous fact collecting. Likewise the demonstration of the biological affinities of human with particular nonhuman form by Thomas Henry Huxley in Evidence as to Man's Place in Nature (1863) was a masterful synthesis based upon an enormous amount of information.

Curiously, although Huxley, Lyell, and later Darwin (1871) dealt with the prehistoric skeletal material known at that time, including the original Neandertal remains, they all avoided the gambit of arranging them in hypothetical lineages purporting to show the course of human evolution. That they should eschew such a step seems an odd bit of caution on the part of the authors whose works embody some of the most daring innovation of the entire nineteenth century. In fact, however, in spite of their very different personalities, all three displayed an intellectual style that came relatively directly from the ethos of the Scottish Enlightenment. Lyell, as intellectual heir of Hutton and Playfair, was born and raised in Scotland (Eiseley, 1959; Wilson [ed.], 1970; Wilson, 1972). Darwin's introduction to both natural science fieldwork and biological theory was in Edinburg just before the effective end of the Scottish Enlightenment (Gruber, $1974: 39,80-81$ ). And, for whatever historical reason, one of the most penetrating observers of the history of science has noted that "Huxley's personal creed was a kind of scientific Calvinism" (de Beer, 1970:917).

Not only did they exemplify the application of the Protestant Ethic in the realm of science (Merton, 1938, esp. pp. 415-419), but, as has been noted for their British contemporaries in the physical sciences (Olson, 1975), the particular style displayed was very much that of the Scottish Philosophy of Common Sense. If the naive extremes of the inductive empiricism of Bacon and Locke were avoided, nonetheless there was a faith that the powers of human reason were sufficient to discover the nature of the world, whose structure was assumed to be logical. And if they recoiled from the extremes of skepticism of a David Hume, and feared the related position of "materialism," at the same time they displayed an elaborate caution when it came to considering anything that could be regarded as a possible projection of the ideals whose loci are primarily in the human mind. Given the nature of the available evidence and the tenor of the times, it is hardly surprising that the examplars of British science in the latter part of the nineteenth century refused to speculate on the possible specifics of a human line of descent.

\section{FRANCE}

If the English were slow to suggest schemes for human phylogeny, the French were even slower. For one thing, even among the few who accepted the possibility of organic evolution, a Darwinian form of mechanism was explicitly rejected (Gaudry, 1878:250, 257; Topinard 1888:473; Stebbins, 1974:138, 164). Furthermore, the effective founder of the field of anthropology in France, Pierre Paul Broca, was an avowed polygenist and vocally unsympathetic to a Darwinian approach (Broca, 1870, 1872; Schiller, 1979:226, 232).

By this time, of course, the whole field of vertebrate paleontology had been in existence for more than a generation following its creation by Georges Cuvier by the beginning of the century (Simpson, 1961:43, Coleman, 1964:2, 114). As the field of human paleontology developed in France late in the nineteenth and early in the twentieth centuries, it adopted an outlook that was rooted in the catastrophism that characterized its older model (Brace, 1964, 1966). Because of the quantity of physical evidence for the form of prehistoric human ap- 
pearance found in France late in the last and early in the present centuries, and because of the interaction of European political and intellectual history, an essentially French viewpoint has played a very important role in shaping the enduring traditions in the field of paleoanthropology.

As a consequence of this, much of the field, especially in France, has continued to show an orientation that has been either covertly opposed to or silent regarding the depiction of schemes that try to arrange the known fossil record into an evolutionary sequence. Even when ultimate human origins are conceded to be "monophyletic," the depiction of subsequent human development is in a "polyphyletic mode" where the lines of development are viewed as proceeding separately in the form of a "bush" (Vallois, 1952:78-79; see Fig. 9; Thoma, 1973; Gould, 1976; de Benoist, 1979). The same analogy has been used by French archaeologists to depict the course of prehistoric cultural development (Bordes, 1950). It is interesting to recall that Cuvier himself insisted that "life was a bush, not a ladder" (Eiseley, 1958:88), although in that instance he was opposing the formulations of those who were attempting to defend an integrated and hierarchical scala naturae.

Finally one must note that a kind of mystical evolutionism was promoted in a French context even though it had no positive impact on the actual study of the course of human evolution. This was initiated by Henri Bergson in

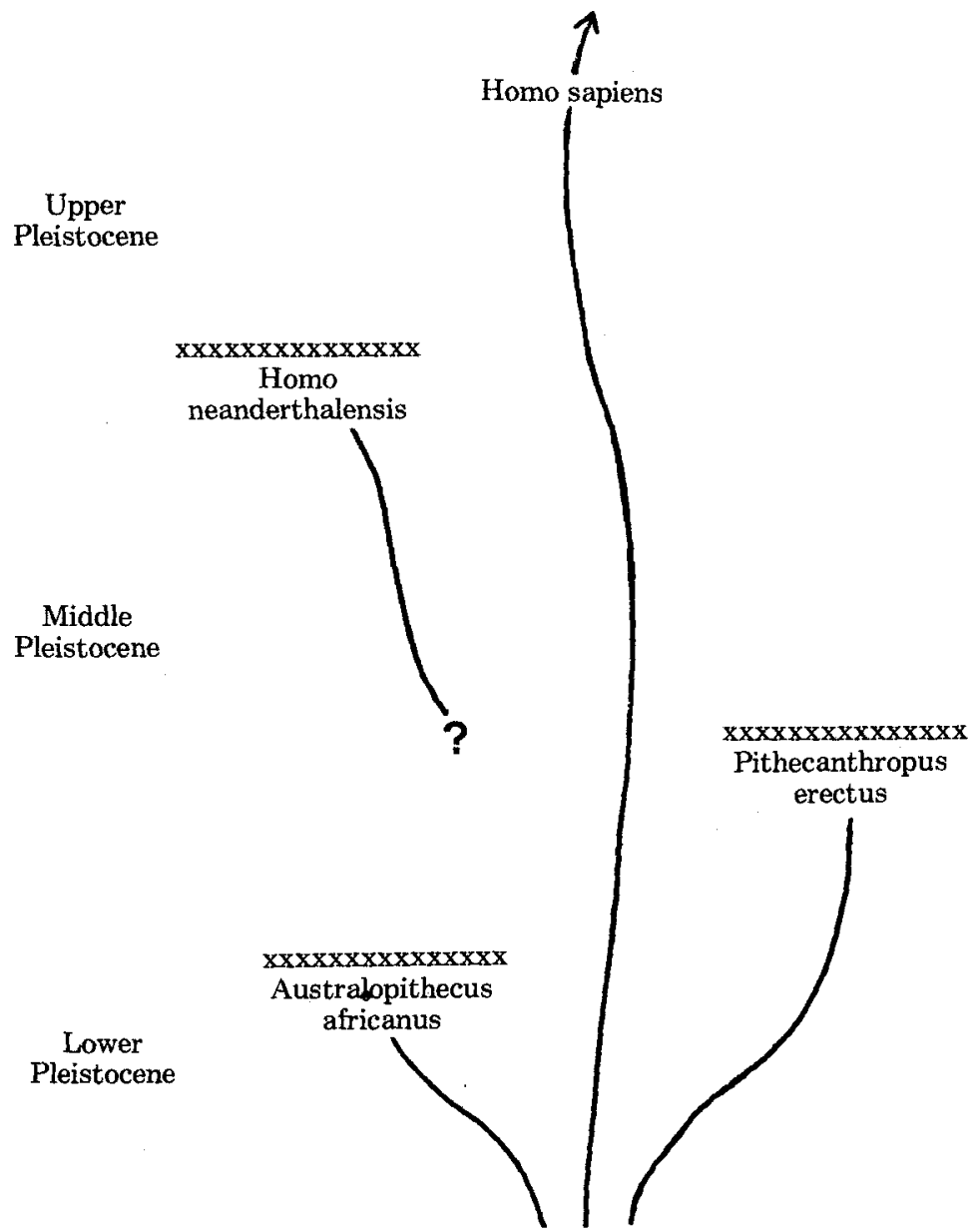

Fig. 9. A version of the polyphyletic formulation favored by French anthropologists, adapted from Vallois (1952:77) with the addition of Australopithecus. All nonmodern fossil hominids are considered to have become extinct without descendants (from Brace et al., 1979:168). 
his Evolution Créatrice (1907) and continued in Teilhard de Chardin, especially his posthumous Le Phénomène Humain (1955). Lovejoy's appraisal of Bergson was written before Teilhard's works were published, but it could serve to characterize them as well. He noted that the central insight of such a philosophy was "a thing to be reached, not through a consecutive progress of thought guided by the ordinary logic available to every man, but through a sudden leap whereby one rises to a plane of insight different in its principles from the level of mere understanding" (Lovejoy, 1936:11-12). As Medawar observed in regard to Teilhard, this "stands square in the tradition of (German) Naturphilosophie" (Medawar, 1967:72), but although he regarded much of it as "nonsense," he added, "on further reflection I see it as a dotty euphoristic kind of nonsense very greatly preferable to solemn long-faced germanic nonsense" (1967:9). In any event it contributed nothing to interpretations of the hominid fossil record.

\section{HAECKEL AND GERMAN ROMANTIC EVOLUTIONISM}

The first formal phylogenetic tree purporting to depict the course of human evolution was the creation of that extraordinary scion of German Naturphilosophie, Ernst Haeckel. The prehistoric portions of this structure, at least in its earliest manifestations, were based on hypothetical constructs. The first of these was "Pithecanthropus" which he included without comment in his system of the mammals in the second volume of his Generelle Morphologie (1866:CLX). At the same time he also suggested the possibility that the term "Erecta" could be used as a taxonomic designation for the human family. In later discussions he added the form "alalus" to serve for "speechless men" while he used "Pithecanthropus" to represent "ape-men" (1870:590, 597). By the end of the century, "alalus" was demoted to become the species name for this hypothetical "Pithecanthropus" and this in turn was considered to be ancestral to Homo sapiens via the further hypothetical form of Homo "stupidus" (1899:35; see Figure 10).

All of this is relatively well known and considered relevant only insofar as it contributed the name which the Dutch physician Dubois later gave to the material he found in Java between 1890 and 1892. Also well known are the different positions which Haeckel and Virchow took in regard to the interpretation of the original Neandertal skeleton and Haeckel's gloating, after having outlived Virchow, when he felt that Dubois' discoveries and Schwalbe's interpretations proved that Virchow had been wrong (Schwalbe, 1901; Haeckel, 1906:108-109). There is more to the story, however, and the point of adding it is to demonstrate how matters of distinctly nonscientific nature can have a bearing on scientific assessment.

Eugène Dubois received his training in Germany and in 1880 was an assistant at the in stitute of anatomy at Jena just at the time that Haeckel's influence was on the rise. It was there that Dubois picked up his interest in evolution and the orientation that he was later to try to apply to the material he collected in Java (Weinert, 1947:33). It is interesting to note that Dubois first referred to the famous Trinil discovery as "Anthropopithecus," (1891), the term Haeckel used for the chimpanzee. When he found the femur, he kept the same generic designation although he changed the species from "troglodytes" to erectus (1892). In his full published report he recognized that he had more than a chimpanzee, and it was then that he used Haeckel's generic term for "apeman" and called it "Ptihecanthropus erectus" (1894). He presented substantially the same views at the third International Congress of Zoology at Leyden in 1895 (Dubois, 1896).

Then, as has often been noted, he remained silent on the matter for more than 20 years and refused to let visitors see his material (Spencer, 1979:415-420). Finally, when he did resume consideration of it, he had undergone a radical change of mind and regarded his "Pithecanthropus" not as a transition form but as a giant extinct gibbon (Dubois, 1932, 1935). Some of the accounts tend to lead the reader to suspect that Dubois had become a little "queer" (Wendt, 1956:299), but there are some other things that may have been involved. For one thing, the interpretation that regarded his fossil as a giant gibbon had in fact been offered by none other than Virchow at that Leyden Congress in 1895 (Virchow, 1895:746-747). Even though Dubois later claimed that he got the idea from the first edition of Boule's Les Hommes Fossiles (Boule, 1921:109; Dubois, 1935:583), it would appear that it was the influence of Virchow that was of principal importance (Ackerknecht, 1953:203).

The fact that Dubois switched from the Haeckel-oriented views of his youth to those of Virchow, Haeckel's long-time rival, brings us back to the nature of their disagreement. An 


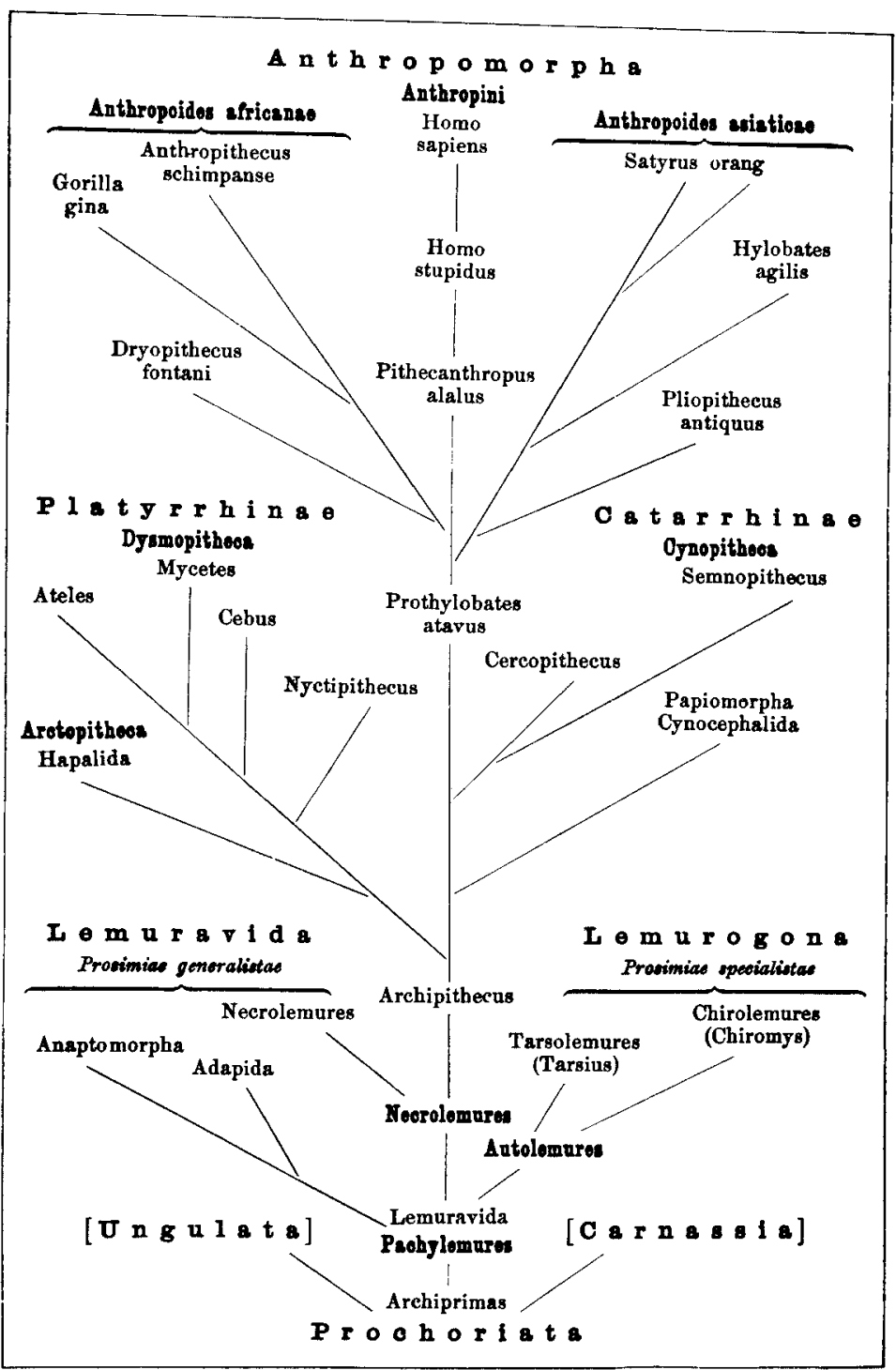

Fig. 10. The Primate family tree according to Haeckel (1899:35).

older reading of the history of science suggested that the issue was where they stood in regard to Darwinian evolution. Haeckel presumably stood for an evolutionary interpretation of both Neandertal and "Pithecanthropus," and Virchow opposed it. The real nature of the Haeckel/Virchow opposition, however, was quite different, and the buffetings suffered by anthropology, however important they may seem to us, were an unintended and relatively inconsequential byproduct of a much more important dispute (Virchow, 1877; Haeckel, 1878; Gasman, 1971).

Haeckel, in fact, in the latter part of the nineteenth century, was busily promoting an aggressive German nationalism of an antiSemitic and anti-Christian (particularly antiCatholic) nature which may well have been painful to Dubois' Catholic sensibilities. In any case, the movement of which Haeckel was 
an active part resulted in a gigantic armed conflict that swirled around the edges of Dubois's own small country. A possible index of Dubois's feelings can be seen in the fact that, after World War I was over and he returned to the arena of scholarly publications, he changed the spelling of his given name from its German form (Eugen) to its French one (Eugène) and ceased entirely to use the German language as the medium for his reports. Whatever the truth may be, it is clear that Dubois' switch from the position advocated by Haeckel to that defended by Virchow cannot be explained by a consideration of the anatomical and paleontological data available at the time.

If some thought that Haeckel simply represented Darwin written in German, the reality was quite otherwise. As Gasman has written:

Although he considered himself to be a close follower of Darwin and ... invoked Darwin's name in support of his own ideas and theories, there was, in fact, little similarity between them. Haeckel himself thought of evolution and science as the domain of religion and his work therefore assumed a character which was wholly foreign to the spirit of Darwin. Darwin's empiricism, his caution in the face of speculative theories, his general mechanical conception of the workings of nature were all in striking contrast to Haeckel's biology. For
Haeckel, evolution did not only mean the process of change from one species to the next. Evolution for him was a cosmic force, a manifestation of the creative energy of nature.

(Gasman, 1971:11)

What Virchow, the cautious, empirical liberal really feared was not materialism or mechanistic evolutionism but the elevation of Haeckel's peculiar brand of evolutionary mysticism to the status of a state religion (Virchow, 1877). The subsequent course of German history has shown that Virchow's fears were fully justified. As the most careful appraisal has shown, Haeckel displayed "a romantic rather than a materialist approach to biology ... The content of the writings of Haeckel and the ideas of his followers - their general political, philosophical, scientific, and social orientation - were proto-Nazi in character ... a prelude to the doctrine of National Socialism" (Gasman, 1971:xiv).

In a major way, this had an impact on the world which has been far more momentous than French romantic evolutionism. One other minor and almost unnoticed casualty was the effort to produce a human phylogenetic tree based on real fossils. This construction was formulated by the Strassburg anatomist, Gustav Schwalbe, and was greeted with considerable satisfaction by Haeckel himself (1906:109). Schwalbe produced two possible arrangements of the then-known erectus, Neanderthal, and modern fossils (see Fig. 11, from Schwalbe, 1906:14). One could almost be regarded as a

\section{Auffassung:}

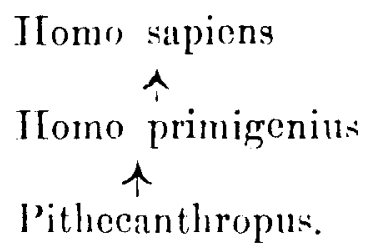

2. $\Lambda$ uffassmug:

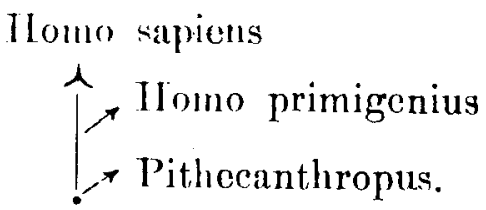

Fig. 11. Two possible arrangements of the known hominid fossils by Gustav Schwalbe. "Homo primigenius" was the term he used for Neandertal (from Schwalbe, 1906:14). 
cladogram, and the other, for which he declared his preference, was a simple phyletic line.

Initially, Schwalbe's formulation was adopted with some approval in England (Sollas, 1908; Keith, 1911 a,b). By the outbreak of the First World War, however, Keith had a complete change of heart $(1915,1925,1931$ $a, b)$, and for the next half-century almost no recognizable vestige of Schwalbe's wellconsidered formulation was to be found. Further, Hrdlicka, in his splendid summary of the known human fossil record, completely misrepresented Schwalbe's position and its significance (Hrdlička, 1930:327). Hrdlička's curious treatment of Schwalbe's views, which were actually quite similar to his own, may have been due to his antipathy for things German (Spencer, 1979:15, 18, 769-770), although this can be no more than informed speculation.

The last pre-World War I phylogenetic scheme associated with German romantic evolutionism was the wondrous concoction by the Breslau anatomist, Hermann Klaatsch (see Fig. 12 from Klaatsch, 1910:567; Wegner, 1910:120). As with the phylogenetic trees of Haeckel, the organizing principle was basically hypothetical, and known fossil and modern specimens were only added after the fact. It had few defenders, and after a blast of criti- cism from Keith $(1910,1911 \mathrm{~b})$, the type of construct which it represented disappeared from serious scientific consideration.

\section{ROMANTICISM AND SIR ARTHUR KEITH}

When the late Lord Snow spoke of "the two cultures," he provided evidence for the fact that the paradigm shift from the Age of Enlightenment to that of Romanticism had not been as all-encompassing as Lovejoy's treatment would lead one to believe (Snow, 1963; Lovejoy, 1936). Snow himself was at home in both a literary and a scientific milieu, although he was aware that this was not true for most intellectuals. In the middle of the nineteenth century, the gulf between the two realms, while appreciable, was not quite so unbridgeable. Charles and Emma Darwin, for example, enjoyed the company of Thomas and Jane Carlyle. Conversely, the historian of philosophy, George Henry Lewes, was given an advance copy of Darwin's Origin to review for Blackwood's (Barzun, 1958:34). After the "Oxford Movement" and the conversion of John Henry Newman in England (1845, see O'Connell, 1969; Weatherby, 1973) and the end of the Scottish Enlightenment (Hook, 1975), however, the gap grew to such an extent that communication between the sides dwindled to the point where some of those who attempted

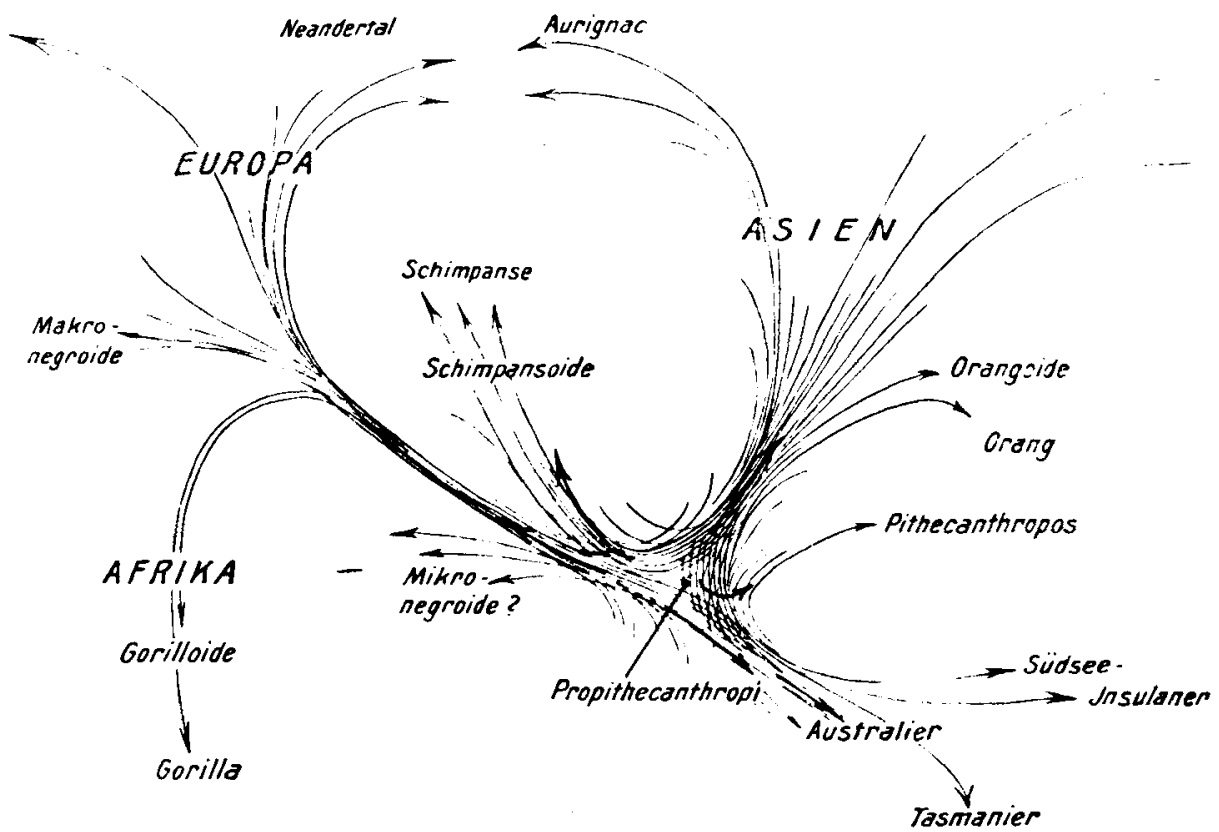

Fig. 12. The hypothetical scheme of human, ape, fossil, and hypothetical forms suggested by Klaatsch (1910:567). 
to provide bridges produced serious misrepresentations instead. One such was Sir Arthur Keith.

Through his numerous books and articles, Keith earned a reputation in England as one of the foremost students of human evolution. $\mathrm{He}$ was a self-proclaimed follower of Darwin (1950:562), and, upon his retirement from the Royal College of Surgeons in London, he spent the rest of his life in a house on the grounds of the Darwin estate at Down -in the eyes of the public, supposedly a continuing symbol of the Darwinian spirit. Some years ago (1964) when I noted that Keith and the majority of the students of the human fossil record displayed a reluctance to interpret the evidence from the perspective of Darwinian evolutionary principles, it was clear that they had bowed to the influence of the non-Darwinian ethos which prevailed in France after the First World War. In the case of Keith, however, I had not realized the extent to which the ground was already prepared for his defection.

Keith specifically mentioned the fact that it was the influence of French paleontology which led to the change in his views (Keith, $1946: 141 ; 1950: 318-319)$. The phylogenetic trees which then served as the frontispieces for his most influential work $(1915,1925)$ had a distinctly French cast to them as Vallois in effect noticed nearly 30 years ago (Vallois, 1952; and see Fig. 13). With changes in dates and some other details, some of the main points of Keith's formulation continue to be apparent in the schemes of his immediate (Hooton, 1931; 1946:413; see Fig. 14; Leakey and Goodall, 1969:108; L.S.B. Leakey, 1965, and interpreted in Cole, 1975:255; see Fig. 15) and more remote (R.E. Leakey and Lewin, 1977:84-85; Kennedy, 1980) intellectual heirs. In his scheme building, however, Keith and his followers did not go to quite the skeptical extremes of the "evolution buissonante" formulations which the French tend to prefer (see Fig. 9 ). Instead they tended to retain some of the speculative continuity that was first apparent in the diagrams of Haeckel.

It is interesting to note, in this regard, that Keith retained a warm admiration for Haeckel (Keith, 1935). Further, Keith's ideas concerning racial purity, and his enthusiasm for war and prejudice as devices for promoting racial development (1931b) are startlingly close to Haeckel and subsequent Nazi racial policy. Like Haeckel, Keith's self-declared enthusiasm for Darwin (cf. 1950:562) masks a more basic commitment to romantic mysticism. In his
Autobiography (1950) he noted his youthful enthusiasm for Thomas Carlyle, and it is clear from a careful reading of his writings that Carlyle continued to remain the dominant influence in his mode of thinking (cf. Keith, 1931b:27). In Darwin's appraisal of Carlyle, he recounted on one occasion his pleasure in listening to Carlyle's discourse (Litchfield [ed.], 1915:II:21), and on another that "I never met a man with a mind so ill adapted for scientific research" (F. Darwin [ed.], 1887:I:64). In some respects, a bit of that judgment could be applied to Keith himself. Although Sir William Bragg, in his presidential address before the British Association for the Advancement of Science in 1928 , chided the outgoing president, Sir Arthur Keith, for his materialism, (Spencer, 1979:74-75), Keith's "materialism" had far more in common with the vitalism of Haeckel (and for that matter Bergson) than with Darwinian mechanism. Keith rejected the role of chance in evolution in a manner quite akin to Paley's "natural theology" of more than a century earlier (Paley, 1802). "I could as easily believe the theory of the Trinity as one which maintains that living developing protoplasm, by mere throws of chance, brought the human eye into existence. The essence of living protoplasm is its purposiveness" (Keith, 1946:217). Then in a passage that could easily have come straight from Haeckel he added, "I have just affirmed that there are evolutionary processes inherent in living things and therefore in Nature-trends of change which are akin to human purpose and human policy" (1946:218). There is little of the cautious empirical Darwin in his writings, and it is interesting how little of Darwinian mechanism is to be found in the schemes of his English and, via Hooton, his American successors.

\section{CLADISTICS}

In order to avoid the manifest subjectivity of the past, and in an effort to make assessments of evolutionary relationship more objectively testable, many students of evolution have recently engaged in the practice of constructing diagrams with twigs and branches called cladograms. These are offered to depict phylogenetic relationships. Although there is more than a little difficulty in rendering time on a cladogram (Delson et al., 1977:265), and this was not even considered when Julian Huxley first proposed the term "clade" (Huxley, 1959), the sharing of "derived"-that is, modified or non-primitive - traits, which is the basis for adjacent placement of terminal twigs, is assumed 


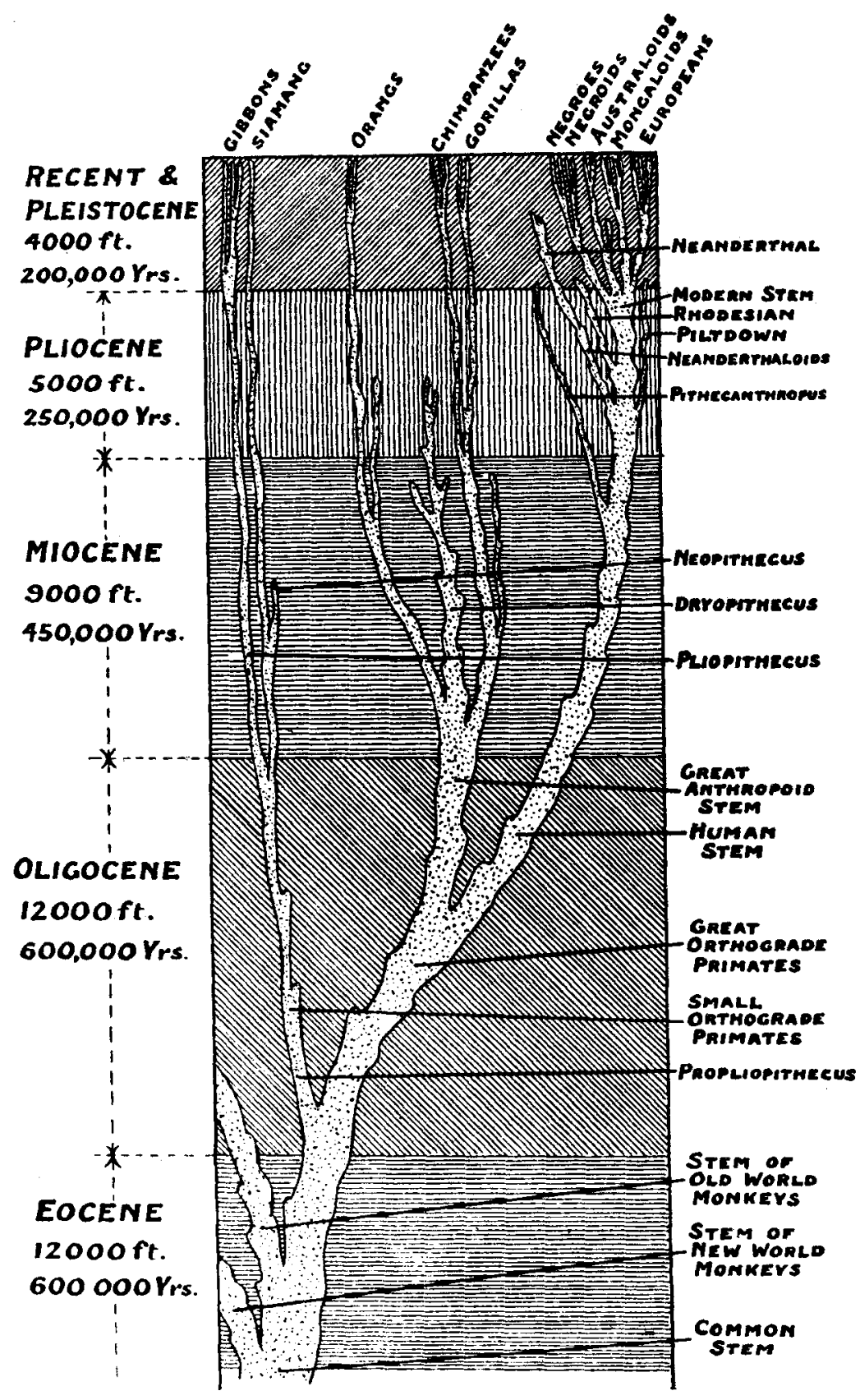




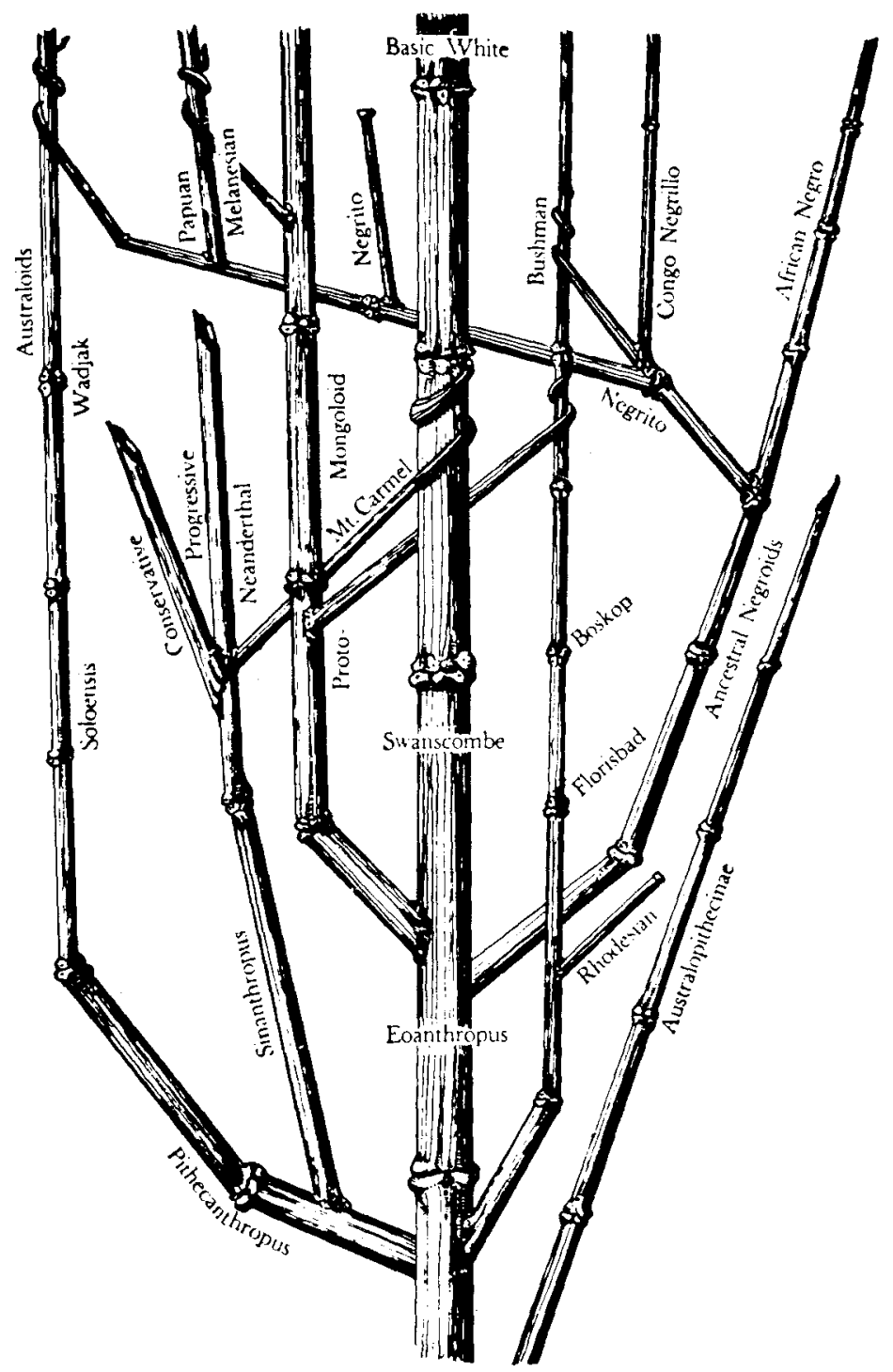

Fig. 14 The refinement of Keith's polyphyletic diagram by Hooton (1946:413)

to be based on recency of descent from a common ancestor (Cain and Harrison, 1960; Mayr, 1974). According to some advocates, "trees should always be based on cladograms" and discussions of evolutionary dynamics should follow after the construction of the trees (Tattersall and Eldredge, 1977:205). Although the proponents of this approach would prefer to label it "phylogenetic systematics" (Eldredge, 1979), the term "cladistics" is a lot easier to get straight and is preferable for a number of reasons (Mayr, 1974:95).
Indeed cladograms based on shared trait states are easy to draw up, and in many instances they may constitute satisfactory depictions of evolutionary relationships (see Fig. 16), but there are some things which they do not handle very well, and a number of scholars have issued caveats with varying degrees of stringency (Mayr, 1974; Van Valen, 1978; Gingerich, 1979). The fact that cladistics has trouble with time is even occasionally offered as a virtue of the approach as shown in the phrase that it represents "phylogency 


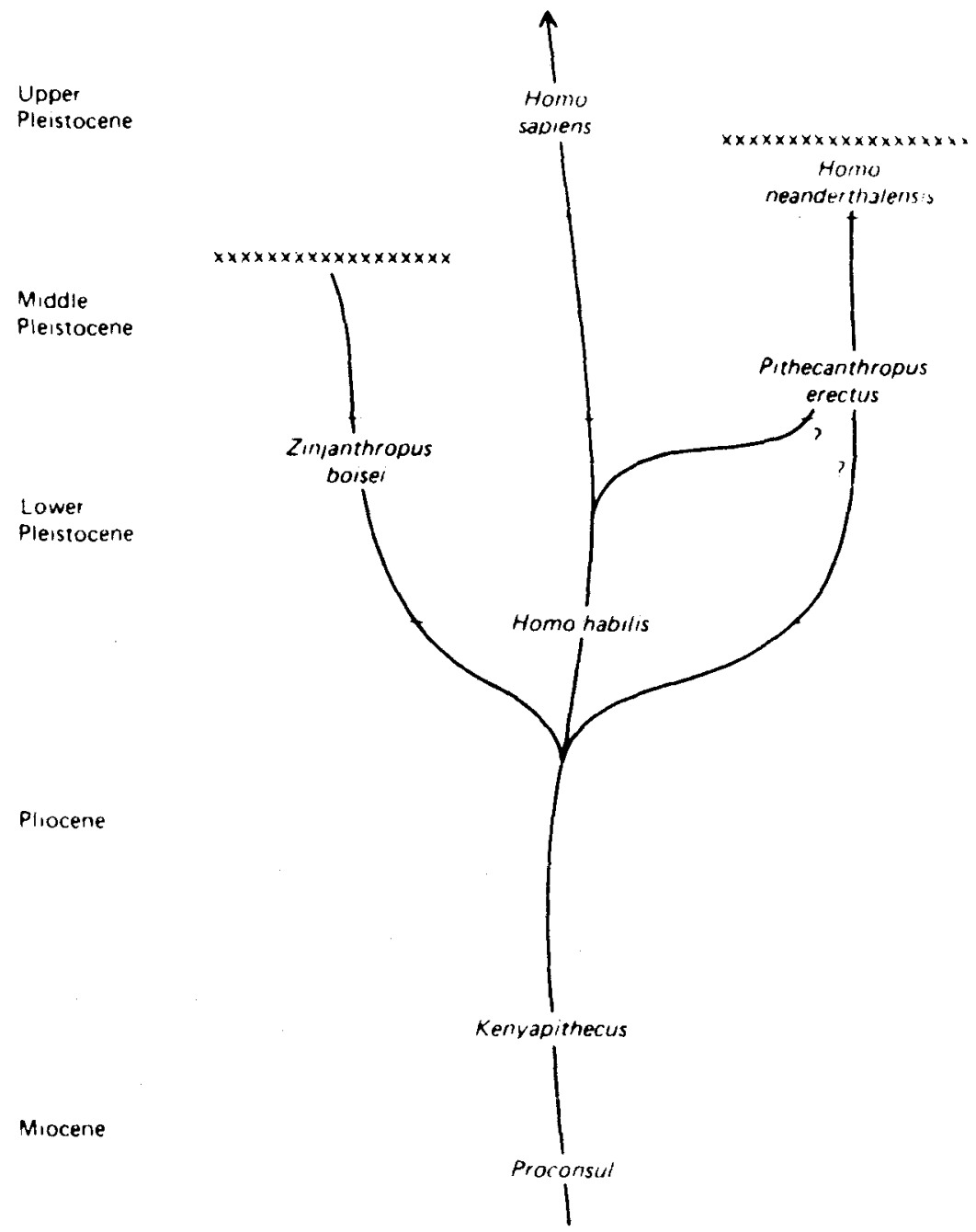

Fig. 15. The family tree preferred by the late L.S.B. Leakey. The only hominid fossil accepted as a possible human ancestor is his own "Homo habilis" (adapted from Leakey, 1965:115 as depicted in Brace et al., 1979:169).

without true time dimension" (Delson et al., 1977:265). Having eliminated a concern for time, the authors go on to decry the attempt to depict ancestor-descendant relationships which they declare to be "untestable." One must grant, of course, that the paleontologist cannot test his problems in the laboratory like a modern chemist, but there are more than a few who do not regard this as sufficient reason for declaring that paleontology ceases to be a science when it deals with matters that are unique to its domain, namely time and relationships. Even the cladist who has noted that "the probability of recognizing ancestors in a fossil sample is zero" goes on to suggest that the likelihood of studying the nature of ancestry is "quite substantial" (Vrba, 1980:77).
Aside from the problem of dealing with time, which surely is crucial for any study of evolution (Van Valen, 1978), there are two other matters that cladistics has trouble handling. One of these is the problem of differing rates and times of change for different traits within a single line or between related lines, i.e., mosaic evolution (Mayr, 1974). In the case of hominid evolution, for example, the timing of changes in brain size (Holloway, 1980a,b) and tooth size (Brace, 1979a,b,c) is quite different, with the result that there are still major questions in regard to the cladistic affinities of more than a few important early hominids.

Another problem that clouds the practice of cladistic analysis is the matter of continuing change after a given branch point. As Mayr 


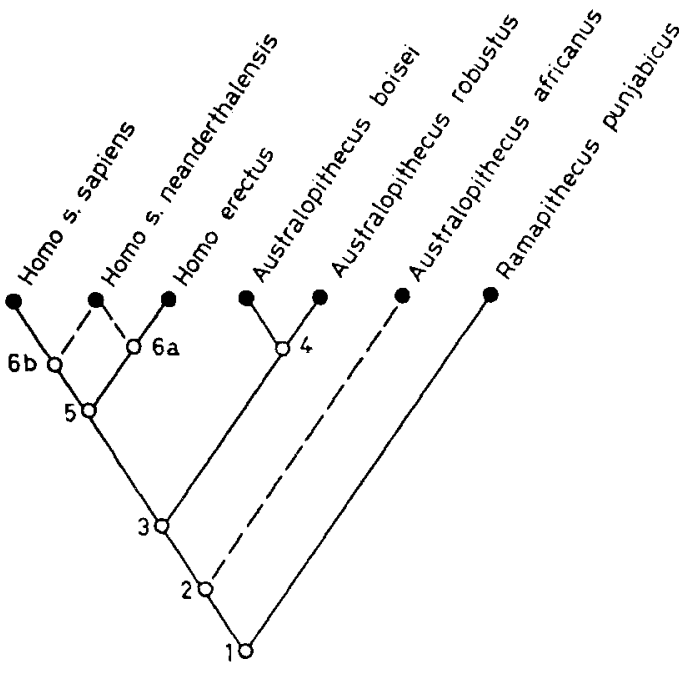

Fig. 16. An example of a plausible hominid cladogram (Eldredge and Tattersall, 1975:235).

has noted (1971:16, 17), cladistics ignores the distinction between evolutionary parallelism and evolutionary convergence, but one could go further and observe that it cannot handle phyletic divergence either (cf. Eldredge and Cracraft, 1980:73-74). It is perfectly possible for forms to diverge after a branch point and then later reconverge to produce a misleading picture of phyletic affinity. Turner's depiction of a possible connection between the Hoabinhian people of the Southeast Asian Mesolithic and the Jomon people of Japan may well be a case in point (Turner, 1979).

Cladistic analysis in fact assumes that the main significant steps in evolution take place at branch points and that what happens subsequently is of considerably less importance. Inevitably those who favor the use of cladograms to illustrate phylogenetic relationships also prefer to regard evolution as primarily a process of fits and starts. This is embodied in the term "punctuated equilibria" to describe the course of organic change (Eldredge and Gould, 1972; Hecht, et al., 1974). The promoters of this approach in fact seem to have taken one of Simpson's three major modes - quantum evolution (Simpson, 1944:198, 206; 1953: 389-393) - and elevated it to a position of principal importance. As has been abundantly demonstrated (cf. Vrba, 1980), there are many instances where species appear suddenly in the fossil record and enjoy long periods of apparent stasis before vanishing. Whether or not the initial shaping was done in a small, isolated and peripheral population is another matter entirely. In fact the extreme exponents of cladistics reject any concern for evolutionary dynamics as a matter of principle (Gaffney, 1979:88).

It is also clear from the data of paleoanthropology that gradualism does occur despite the bald but unsupported statement to the contrary by Gould and Eldredge (1977:135). Hominid brain size doubled over a span of 1.5 million years until it effectively reached its modern size some time before the onset of the last glaciation. Subsequently it evidently has displayed the expected equilibrium, but at the same time human tooth size has reduced by a full $50 \%$ in a broad belt running from Europe to Japan (Brace, 1979b, and in preparation). Although this dental change may seem like a sudden event in the full span of evolutionary time, it was not accompanied by speciation, it did not take place in isolation, nor was it particularly peripheral. Furthermore, the preceding expansion in brain size took place gradually over a suitably long period of evolutionary time and evidently was shared by the entire hominid population.

Those who have been principally behind developing the picture of punctuated equilibria, whether or not they are proponents of cladistics, have placed it in opposition to the models of evolutionary gradualism which they have traced to the world views and political philosophies of the initial proposers, principally Darwin, Lyell, and their English contemporaries (Gould, 1977). Others of course have noted that Darwin's views were very much a product of his background. Karl Marx, writing to Engels, observed, "It is remarkable how Darwin recognizes among beasts and plants his English society . . ." (Schmidt, 1962:37). Commenting on the continuing favor with which Darwinian ideas are held, Gould and Eldredge have noted, "The general preference that so many of us hold for gradualism is a metaphysical stance embedded in the history of western cultures: It is not a high-order empirical observation induced from the objective study of nature" (1977:145).

The possibility must be considered, however, that there may be just as much of social conditioning inherent in the recent enthusiasm for punctuated equilibria as opposed to gradualism. Not only are many of the supporters products of an affluent post-World War II milieu in which instant gratification was accepted as due, but as the originators of the view have noted, "it may also not be irrelevant to our personal preferences that one of us learned his Marxism literally at his daddy's knee" (Eldredge and Gould, 1977:146). 
Finally, one can suggest that the origins of the paleontological traditions in the scholarship of nineteenth-century France may also be of some consequence. The current in modern paleontology that accepts the discontinuous nature of the stratigraphic record as indicative that the history of organic life has been discontinuous (Gould, 1965), the emphasis on sudden, dramatic change (Gould, 1974, 1978a,b), and the stress on speciation events in small, isolated groups remote from the area of consideration followed by sweeping take-overs, all are remarkably similar to the outlook that characterized nineteenth-century French paleontology. A century ago this contributed to the French rejection of the idea of evolution by means of natural selection. Its reemergence today in the writings of a generation of paleontologists who have not looked carefully into the traditions of the field in which they have been trained could well lead to its being designated "neocatastrophism" (Brace, 1978:983). In view of what we can suspect is the lurking French connection, it would be appropriate here to recall what the French would say in this regard: Plus ça change, plus c'est le même chose.

\section{THE HOMINID PHYLETIC PICTURE}

If the interpretive styles of a century ago are still with us in several guises, in addition a quantity of fossil material has been accumulated that was simply undreamed of by the empirically oriented thinkers who framed the first evolutionary syntheses. Given what we now possess, the possibility of building various kinds of descent "scenarios" is almost inevitable. As has already been noted, Gustav Schwalbe made the first attempt to deal with the known hominid fossils early in this century from what would now be regarded as the perspective of "evolutionary systematics" (see Fig. 11). Although this was largely forgotten with the eclipse of German views that generally occurred following World War I, the approach was not entirely without subsequent development. Over 40 years later and bolstered by many more fossils, Schwalbe's student and, briefly, successor at Strassburg, Franz Weidenreich, produced a sophisticated elaboration (Fig. 17, from Weidenreich, 1947:201; and see also Weidenreich, 1946a:24). By this time, however, the paradigm which governed interpretation in paleoanthropology, despite some lip-service to Darwin, was largely that of the French tradition. As a consequence, in the few instances where Weidenreich's work has been mentioned, it has been seriously misrepresented. One major work, actually dedicated to Weidenreich in memoriam, stressed the long-continued geographic isolation of separate developing hominid lines (Coon, 1962). Another redrew his diagram to remove all of the connecting lines that indicated contact between geographically adjacent populations and then labeled it the "Polyphyletic or Candelabra School" (Howells, 1967:241). In fact, however, the polyphyletic stress on regional isolation was more a reflection of the expectations of the readers than it was inherent either in Weidenreich's diagrams or his discussion.

In their appraisal of the dynamics of hominid evolution, both Weidenreich and Dobzhansky (1944) noted that, once the level of the genus Homo had been reached, the geographic isolation that would lead to local speciation would no longer occur (Weidenreich, 1943b:253, 1946b:414). Gene flow across population boundaries then would be sufficient so that the genus would contain a single albeit regionally differentiated species. If, as Dobzhansky noted, modern Homo sapiens constitutes a "single polytypic species" (Dobzhansky, 1944:265), the expectation was implicit that the same thing should have been the case for the previous history of the genus Homo. This was the basis for the suggestion that, prior to the appearance of what we recognize as "modern" form, the human line passed through a grade of organization (cf. Huxley, 1958) characterized by larger jaws and teeth and a skeleton displaying greater robustness and more pronounced muscle markings. The first such prehistoric skeleton to be recognized was the one discovered in the Neanderthal in 1856 , and there are some scholars who felt that this was reason enough to attach that name to the stage through which human form had passed before reaching its modern configuration (Hrdlicka, 1927, 1930; Weidenreich, 1928, 1943a; Brace, 1964).

This does not mean, as some have assumed, that the European Neandertals gave rise to the modern Chinese-or Africans or Indonesians. Instead it means that one would expect to find that the local predecessors of Chinese, Africans, and Indonesians - and any other modern population where continuity in situ can be expected extending back to the last interglacial-would display a degree of robustness in teeth, jaws, skeletons, and muscle markings comparable to that observed in the European Neanderthals. The idea of a polytypic Neanderthal Stage as the antecedent to modern forms of Homo sapiens has been criticized for many reasons (Howells, 1974, 1976; Thoma, 1973, 1975; Santa Luca, 1978), 


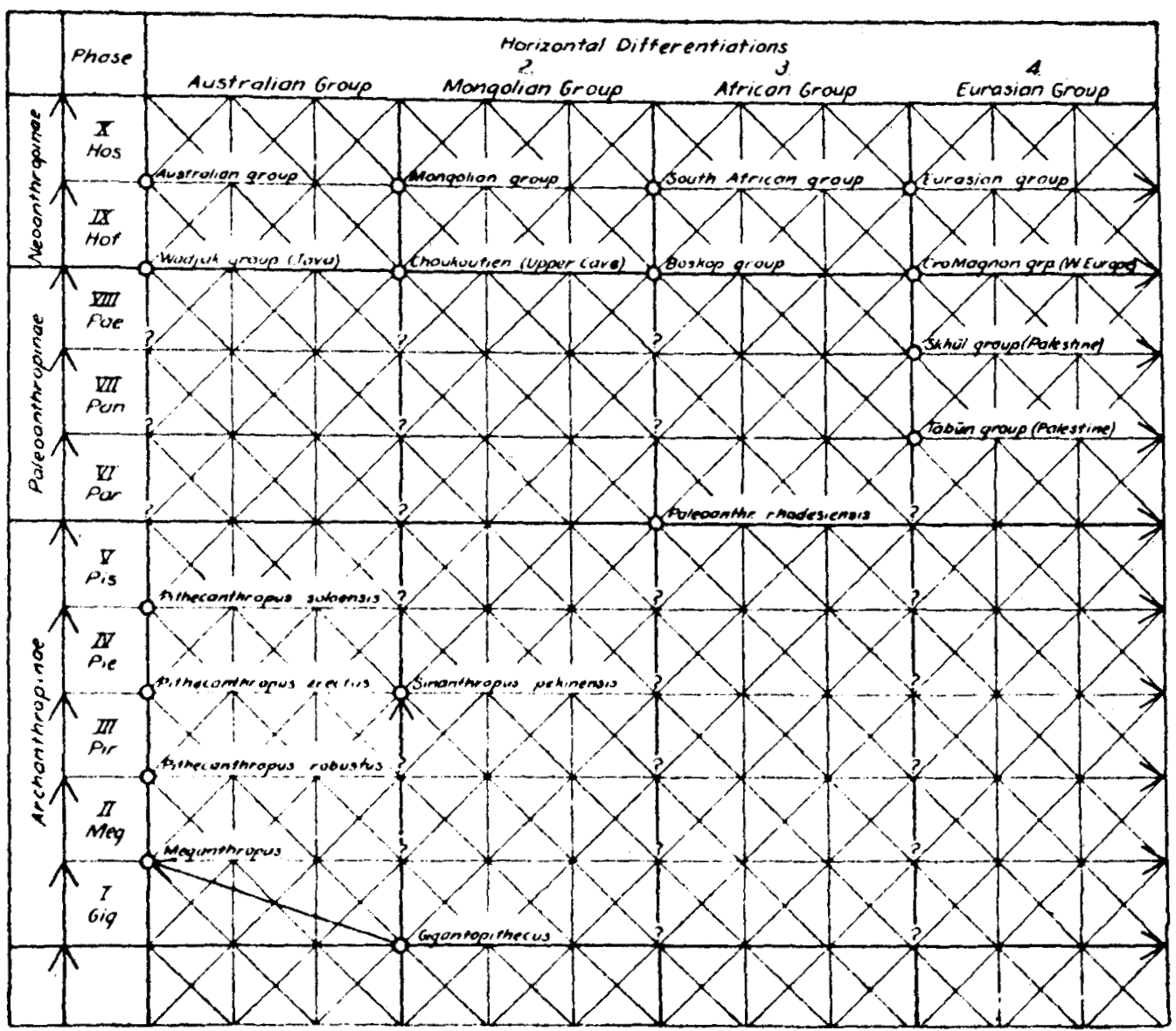

Fig. 17 This famous diagram is more scenario than tree, and has more implications than the simple designation of "polyphyletic" would lead one to believe (Weidenreich, 1947:201)

but it still seems more useful than the alternatives available which, at best, are largely cladistic in nature. As Mayr has put it, "It results in a great deal of loss of information to ignore the adaptive component of evolution expressed by the concept of grade. . ." (Mayr, 1974:107).

In Europe itself, where the evidence collected is more abundant and better known than anywhere else, the most thorough recent analyses have shown that the transition of Neanderthal to modern tooth and face form occurs gradually and without any break (Brace, 1979b; Smith and Ranyard, 1980), and it is clear that there is no reason why such a transition could not be documented for the postcranial skeleton as well (Trinkaus, 1976, 1977). In Africa, the evidence is scrappier and the dating much more tentative, but there is nothing inherent in the material from Omo
(Kibish) to Florisbad (Day, 1969; Rightmire, 1978) or anything in between (Robbins, 1972) that would contradict such a view. And in China, Mapa and the recently discovered $\mathrm{Da} \mathrm{Li}$ skull lexamined at the Institute of Vertebrate Paleontology and Paleoanthropology in Beijing, 1980, courtesy of Prof. Wu Xin-zhi) make splendid Neanderthal Stage precursors of the modern Chinese. Finally, the evidence from In donesia also is consistent with a picture of in situ continuity from early Middle Pleistocene erectus to Solo and possibly via Wadjak to modern Australian form.

At the Neanderthal level, the quantity of material available from widely dispersed areas creates the very real problem of whether a single term is adequate to encompass it all. In spite of the efforts of pheneticists and cladists to reduce taxonomy to a rigidly defined and presumably objective science, the element of 
"art," as Simpson has noted (Simpson, 1961:110, 227), will continue to remain in the practice of the proverbial "competent systematist" (Carter, 1951:118-119).

Earlier in the course of hominid evolution, there is another problem which is just as difficult to deal with. This involves the question of how to designate continuous change through time. Of course, one solution is simply to deny that the hominid phyletic line gradually evolved from one species into another, which is precisely the tack taken by one recent survey (Stanley, 1979:80-82). Otherwise, if full cladistic logic were followed (Eldredge and Cracraft, 1980:114, 244), we would still belong to Australopithecus a fricanus if indeed the last splitting event in hominid evolution occurred when africanus and boisei differentiated.

Most paleoanthropologists, however, accept an in situ transition from Australopithecus to Homo at the generic level and then from erectus to sapiens at the specific level. The problem, then, is the classic one of successive species - where to draw the lines, and what to call the lineage and when. When we only had a few points in time represented, it was easy enough to give them names without regard to whether the entities named were discrete events of points on a continuum - the "piers" of Sollas's "ruined bridge which once continuously connected the kingdom of man with the rest of the animal world" (Sollas, 1908:337). While the gaps remained, they provided room either for the presence of a presumed "God," or justification for the specific essentialism preferred by the cladists.

Now, however, the accumulation of recent discoveries has confirmed Sollas's assumptions. While this is gratifying to those with Darwinian expectations, it has created the terminological problems alluded to above. At the earliest level, "afarensis" has been proposed as specifically distinct from africanus because of its possession of a series of features that are clearly more primitive (Johanson and White, 1979) - "plesiomorphic" in the cladistic lexicon. But the differences in these traits are no greater than those by which modern human "races" are distinguished, and they indicate at most that africanus had simply been pursuing the same adaptive strategy for a longer period of time. If the same logic were rigorously applied to the recent hominid fossil record, then the Neanderthals would once again warrant a separate specific designation from sapiens. Even the Skhül specimens and possibly such early Upper Paleolithic groups as Predmost would have to be consigned to separate species. All of this remains unresolved even though there can be little doubt concerning the probable status of the Hadar and Laetoli specimens as representing the condition ancestral to all subsequent hominids.

At a slightly more recent level of time, the same sorts of problems (and more) becloud the status of what has been called "habilis." Using the most numerous data available, namely, tooth measurements, a kind of "stratophenetic" (cf. Gingerich, 1976, 1979) arrangement has been made which then is used to defend a tree in which "habilis" is regarded as the direct descendant of "afarensis" and the immediate precursor of erectus (Johanson and White, 1979:327-328). A similar scheme has been defended using multivariate distance measures (McHenry and Corruccini, 1980:1104).

While this may very well be correct, it does not tell us when to change the generic or even the specific names. Further, it is just possible that the legitimate $H$. erectus and $A$. africanus specimens may have been lumped from different sites and time periods to make up the "habilis" group in the first place (Brace et al., 1973). Part of the difficulty has been caused by the prolonged delay in the proper comparative treatment of the original material on which the proposed taxon was based.

Even Holloway's recent suggestion that the braincase of the type specimen, $\mathrm{OH} 7$, warrants the designation Homo can be challenged on solid quantitative grounds (Holloway, 1980b:273; Wolpoff, in press). His further comment that final taxonomic placement will have to await the appraisal of the dentition raises another major problem, even though the one comparative and quantitative treatment of the dentition published has shown that the teeth of the type specimen cannot be distinguished from Australopithecus africanus (Brace et al., 1973).

But the problem is that the brain and the teeth may very well be following separate evolutionary courses. This certainly was true late in the Pleistocene where brain size did not change at all but the dentition reduced by up to $50 \%$ (Brace, 1979a,b,c). Mosaic evolution is not only difficult for cladists to handle, it is difficult for the evolutionary systematist to represent in the form of a tree. At this point we are back to the "art" in Simpson's taxonomic practice. Even the complex schemes offered (cf. Fig. 17; Brace, 1979c:105) are cluttered and difficult. One solution is to indicate the core of 
the tree by points based on the data from one evolving dimension and then subjectively depict a trunk that is wide enough to include a number of the detailed schemata that have been proposed. This is done in Figure 18 (from Brace et al., 1979:173). Whether this can accomodate the resolution of the brain size issue and the data from other dimensions that will eventually be considered is impossible to predict at the present time. At least it provides a framework for the various contending hypotheses that are currently being considered.

It is evident from the variations that are produced by the use of the different measures or their combinations that such simple quantitative procedures do not give us a single Platonic truth. Even the summed use of metrics representing the considerable amount of teeth available to us-however satisfying some of us may think this to be-only gives us a picture of evolution in one dimension. If we

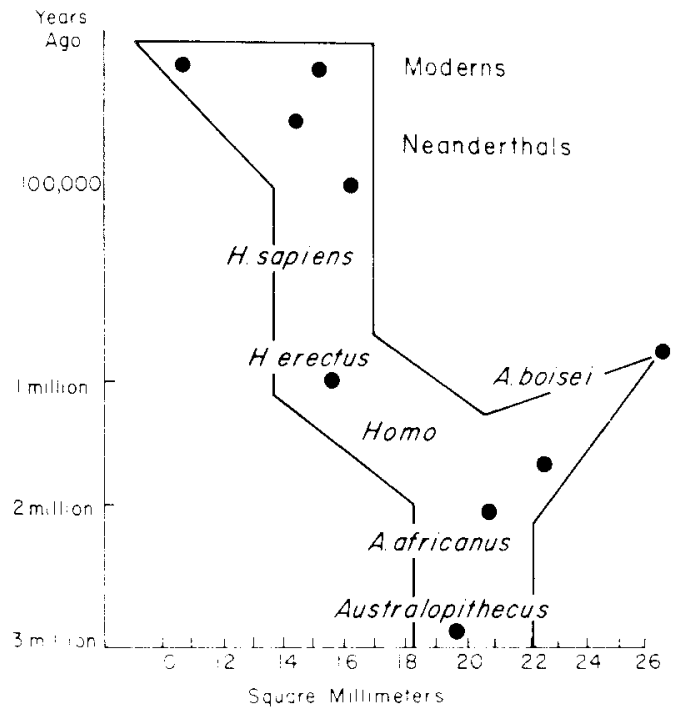

Fig. 18. The dots within this tree are based on actual data points, sums of mean cross-sectional areas for the teeth in the dental arches of the populations named. The lowest dot is based on the material from Hadar and Laetoli. The dot between africanus and boisei is from the material at Swartkrans and Kromdraai. The earliest dot in the sapiens section is from the Krapina Neanderthals. The classic Neanderthals of western Europe are just above that, and the two dots at the top display the range between Australian aborigines and modern Europeans. (From Brace et al., 1979:173, based on data recorded in Brace, 1979a,b). were to have similar quantities of information for other traits, many would present pictures that are quite different. Both schematic simplicity (Fig. 18) and indications of considerable complexity (Fig. 17) have their utility. No one has a monopoly on "truth." Although it is legitimate to feel that many have helped increase our understanding of the dynamics by which humanity emerged, it is just because we can never know the whole of that "truth" that a multiplicity of schemes will continue to be constructed and will continue to be of value. ${ }^{1}$

\section{ACKNOWLEDGMENTS}

The text of this paper is a revision of the presentation made at Charlottesville, Virginia on December 11, 1980 at the meeting commemorating the fiftieth anniversary of the founding of the American Association of Physical Anthropologists. I am grateful to Drs. Frank Spencer and Noel T. Boaz for inviting me to be on the program at Charlottesville and for arranging for the publication, in the American Journal of Physical Anthropology, of a paper which would otherwise have been rejected because of its failure to comply with standard editorial policy.

${ }^{1}$ In the past, I have often closed my comments with a bit of doggerel from the pen of $I$. Doolittle Wright. His efforts, however, have been limited to the use of the limerick form, and given the serious nature of the present occasion, it occurs to me that a more appropriate mode of expression would be preferable. Since I started the current paper with observations concerning the debt of Darwin and his contemporaries to the ethos of the Scottish Enlightenment, it seemed only fitting to record my own levels of skepticism in suitable Scottish form. Although, as the name shows, he is not a proper Scot, nevertheless Wright's cousin I. Wright Drivell has dabbled in the use of favorite stanza of Robert Burns. In response to Wright's simple certainties, Drivell, acting the veritable killjoy, replied to his cousin crossly with his "Owed to Trees"

As we survey the path we've trod,

Of knowledge gained by labored plod

Now each aspiring learned clod, Will try to see

How he can be a bit like God And make a tree.

The record shows that those who strived, Produced results that look contrived; Are twigs then based on traits derived To make a clade?

Do branches show the route arrived, To reach a grade?

However much they try to please, The schemes expand by twos and threes; The viewer then who thinks he sees, Can only fail.

To tell the forest from the trees, - To no avail. 


\section{LITERATURE CITED}

Ackerknecht, EH (1953) Rudolf Virchow: Doctor, Statesman, Anthropologist. Madison: University of Wisconsin Press.

Barzun, J (1958) Darwin, Marx, Wagner: Critique of a Heritage. 2nd ed. Garden City, NY: Doubleday Anchor Books.

De Beer, G (1970) Thomas Henry Huxley. Encyclopaedia Britannica, Chicago: University of Chicago, 11:916-918.

de Benoist, A (1979) La ruée vers l'homme. Le Figaro magazine, Feb. 3, p. 40.

Bergson, H (1907) L'Evolution Créatrice. Paris: Alcan.

Bordes, F (1950) L'evolution buissonante des industries en Europe occidentale. Considérations théoriques sur le Paléontologie ancien et moyen. L'Anthropologie 54:393-420.

Boule, M (1921) Les Hommes Fossiles: Eléments de Paléontologie Humaine. Paris: Masson.

Brace, CL (1964) The fate of the "classic" Neanderthals: A consideration of hominid catastrophism. Curr. Anthropol. $5: 3-43$

Brace, CL (1966) More on the fate of the "classic" Neanderthals. Curr. Anthropol. 7:210-214.

Brace, CL (1978) Review of Ontogeny and Phylogeny by Gould, SJ. Am. Anthropol. 80:982-984.

Brace, CL (1979a) Biological parameters and Pleistocene hominid life-ways. In IS Bernstein and EO Smith (eds): Primate Ecology and Human Origins: Ecological Influences on social Organization. New York: Garland Press, pp. 263-289.

Brace, CL (1979b) Krapina, "classic" Neanderthals, and the evolution of the European face. J. Hum. Evol. 8:527-550.

Brace, CL (1979c) The Stages of Human Evolution: Human and Cultural Origins. 2nd ed. Englewood Cliffs, NJ: Prentice-Hall.

Brace, CL (in preparation) Tooth size in Japan, past and present.

Brace, CL, Mahler, PE, and Rosen, RB (1973) Tooth measurements and the rejection of the taxon "Homo habilis."Yrbk. Phys. Anthropol. 16:50-68.

Brace, CL, Nelson, H, Korn, N, and Brace, ML (1979) Atlas of Human Evolution. 2nd ed. New York: Holt, Rinehart, and Winston.

Broca, P (1862) La linguistique et l'anthropologie. Bull. Soc. d'Anthropol. Paris 3:264-319.

Broca, P (1870) Sur le transformisme. Bull. Soc. d'Anthropol. Paris $2^{2}$ Sér. 5:168-242.

Broca, $\mathbf{P}(1872)$ Les sélections, la descendance de l'homme, la sélection sexuelle de Darwin et la sélection naturelle de Wallace (revue critique). Rev. d'Anthropol. 1:683-710.

Cain, AJ, and Harrison, GA (1960) Phyletic weighting. Proc. Zool. Soc. Lon. 135:1-31.

Carter, GS (1951) Animal Evolution: A Study of Recent Views of Its Causes. London: Sidgwick and Jackson.

Cole, S (1975) Leakey's Luck. New York: Harcourt Brace Jovanovich.

Coleman, WR (1964) Georges Cuvier, Zoologist: A Study in the History of Evolutionary Theory. Cambridge, Mass: Harvard University Press.

Coon. CS (1962) The Origin of Races. New York: Alfred A. Knopf.

Darwin, C (1859) On the Origin of Species by Means of Natural Selection, or the Preservation of Favoured Races in the Struggie for Life. London: John Murray.

Darwin, C (1871) The Descent of Man and Selection in Relation to Sex. 2 vols. New York: D. Appleton.

Darwin, C (1872) On the Origin of Species by Means of
Natural Selection, or the Preservation of Favoured Races in the Struggle for Life. 6th ed. London: John Murray.

Darwin, F (ed) (1887) The Life and Letters of Charles Darwin Including an Autobiographical Chapter. 2 vols. New York: D. Appleton.

Day, MH (1969) Omo human skeletal remains. Nature 222:1135-1138.

Delson, E, Eldredge, N, and Tatttersall, I (1977) Reconstruction of hominid phylogeny: A testable framework based on cladistic analysis. J. Hum. Evol. 6:263-278.

Dobzhansky, $\mathrm{T}$ (1944) On the species and races of living and fossil man. Amer. J. Phys. Anthropol 2:251-265.

Dubois, E (1891) Palaeontologische onderzoekingen op Java. Verslag van het Mijnwezen over het $3^{\text {c }}$ Kwartaal, pp. 12-14.

Dubois, E (1892) Palaeontologische onderzoekingen op Java. Verslag van het Mijnwezen over het $3^{*}$ Kwartaal, pp. 10-14.

Dubois, E (1894) Pithecanthropus erectus, Eine menschenähnliche Uebergangsform aus Java. Batavia Landesdruckerei.

Dubois, E (1896) Pithecanthropus erectus eine menschenähnliche Uebergangsform. C.R. Troisième Congrès International de Zoologie, Leyden, pp. 251-271.

Dubois, E (1932) The distinct organization of Pithecanthropus, of which the femur bears evidence now confirmed from other individuals of the described species. Proc. Kon Akad. van Wetenschappen te Amsterdam 35:716-722.

Dubois, E (1935) On the gibbon-like appearance of Pithecanthropus erectus. Proc. Kon. Akad. van Wetenschappen te Amsterdam 38:578-585.

Eiseley, LC (1958) Darwin's Century: Evolution and the Men Who Discovered It. Garden City, NY: Doubleday.

Eiseley, LC (1959) Charles Lyell. Sci. Am. 201:98-106.

EIdredge, $N$ (1979) Cladism and common sense. In J Cracraft, and N Eldredge, (eds): Phylogenetic Analysis and Paleontology. New York: Columbia University Press, pp. 165-198.

Eldredge, N, and Cracraft, J (1980) Phylogenetic Patterns and The Evolutionary Process: Method and Theory in Comparative Biology. New York: Columbia University Press.

Eldredge, N, and Gould, SJ (1972) Speciation and punctuated equilibria: An alternative to phyletic gradualism. In Schopf, TJ (ed): Models in Paleobiology. San Francisco: Freeman pp. 85-120.

Frazer, JG (1887) Totemism. Edinburgh: Adam and Charles Black.

Freud, S (1950) Totem and Taboo: Some Points of Agreement Between the Mental Lives of Savages and Neurotics. Translated by James Strachey. London: Routledge and Kegan Paul.

Gaffney, ES (1979) An introduction to the logic of phylogenetic reconstruction. In $\mathrm{J}$ Cracraft and $\mathrm{N}$ Eldredge (eds): Phylogenetic Analysis and Paleontology. New York: Columbia University Press pp. 79-111.

Gasman, D (1971) The Scientific Origins of National Socialism: Social Darwinism in Ernst Haeckel and The German Monist League. London: McDonald.

Gaudry, A (1878). Les Enchainements du Monde Animal dans le Temps Géologiques: Mammifères Tertiares. Paris: Masson.

Genovés, TS (1964) Comment on the fate of the "classic" Neanderthals: A consideration of hominid catastrophism. Curr. Anthropolo. 5:22-25.

Gingerich, PD (1976) Paleontology and phylogeny: Patterns of evolution at the species level in early tertiary mammals. Am. J. Sci. 276:1-28. 
Gingerich, PD (1979) The stratophenetic approach to phylogeny reconstruction in vertebrate paleontology. In J Cracraft and N Eldredge (eds): Phylogenetic Analysis and Paleontology. New York: Columbia University Press. pp. 41-77.

Glick, TF (ed) (1974) The Comparative Reception of Darwinism. Austin: University of Texas Press.

Gould, SJ (1965) Is uniformitarianism necessary? Am. J. Sci. 263:223-228.

Gould. SJ (1974) The great dying. Nat. Hist. 83:22-27.

Gould, SJ (1976) Ladders, bushes and human evolution. Nat. Hist. 85:24-31.

Gould, SJ (1977) Evolution's erratic pace. Nat. Hist. 86:12-16.

Gould, SJ (1978a) Evolution: Explosion, not ascent. New York Times, Jan. 22, p. E6.

Gould, SJ (1978b) The great scablands debate. Nat. Hist. 87:12-18.

Gould, SJ, and Eldredge, N (1977) Punctuated equilibria: The tempo and mode of evolution reconsidered. Paleobiology 3:115-151.

Greene, JC (1959) The Death of Adam: Evolution and Its Impact on Western Thought. Ames: Iowa State University Press.

Gruber, HE (1974) Darwin on Man: A Psychological Study of Scientific Creativity, Together With Darwin's Early and Unpublished Notebooks. Transcribed and Annotated by Paul H. Barret. New York: E.P. Dutton.

Haeckel, E (1866) Generelle Morphologie der Organismen. 2 vols. Berlin: Georg Reimer

Haeckel, E (1870) Natürliche Schöpfungsgeschichte. 2nd ed. Berlin: Georg Reimer.

Haeckel, E (1878) Freie Wissenschaft und Freie Lehre: Eine Entgegnung auf Rodolf Virchow's Münchener Rede über Die Freiheit der Wissenschaft im Modernen Staat. Stuttgart: E. Schweizebartsche Verlagshandlung.

Haeckel, E (1899) Ueber unsere gegenwärtige Kenntniss vom Ursprung des Menschen. Bonn: Emil Strauss.

Haeckel, E (1906) Last Words on Evolution. Translated from the second edition by Joseph McCabe. London: A. Owen.

Hecht, MK, Eldredge, N, and Gould, SJ (1974) Morphological transformation, the fossil record, and mechanisms of evolution. Evol. Biol. 7:295-308.

Holloway, RL (1980a) Indonesian "Solo" (Nagandong) endocranial reconstructions: Some preliminary observations and comparisons with Neandertal and Homo erectus groups. Am. J. Phys. Anthropol. 53:285-295.

Holloway, RL (1980b) The OH 7 (Olduvai Gorge, Tanzania) hominid partial brain endocast revisited. Am. J. Phys. Anthropol. 53:267-274.

Hook, A (1975) Scotland and America: A Study of Cultural Relations, 1750-1835. Glasgow: Blackie.

Hooton, EA (1931) Up From the Ape. New York: Macmillan.

Hooton, EA (1946) Up From the Ape. 2nd ed. New York: Macmillan.

Howells, WW (1967) Mankind in the Making: The Story of Human Evolution. 2nd ed. Garden City, NY: Doubleday.

Howells, WW (1974) Neanderthals: Names, hypotheses, and scientific method. Am. Anthropol. 76:24-38.

Howells, WW (1976) Neanderthal man: Facts and figures. Yrbk. Phys. Anthropol. 18:7-18.

Hrdlickka, A (1927) The Neanderthal phase of man. J. R. Anthropol. Inst. 57:249-269.

Hrdlička, A (1930) The Skeletal Remains of Early Man. Smithson. Miscell. Coll. No. 83 Washington, DC: Smithsonian Institution.

Huxley, JS (1958) Evolutionary processes and taxonomy with special reference to grades. In $\mathrm{O}$ Hedberg (ed): Systematics Today. Uppsala Universitets Arrskrift 1958, $6: 21-39$.
Huxley, JS (1959) Clades and grades. In AJ Cain (ed): Function and Taxonomic Importance. Systematics Assoc. London, Publication 3:21-22.

Huxley, TH (1863) Evidence as to Man's Place in Nature. London: Williams and Norgate.

Johanson, DC, and White, TD (1979) A systematic assessment of early African hominids. Science 203:321-330.

Keith, A (1910) A new theory of the descent of man. Nature 85:206.

Keith, A (1911a) Ancient Types of Man. New York: Harper.

Keith, A (1911b) Klaatsch's theory of the descent of man. Nature 85:509-510.

Keith, A (1915) The Antiquity of Man. London: Williams and Norgate.

Keith, A (1925) The Antiquity of Man. 2nd ed. 2 vols. London: Williams and Norgate.

Keith, A (1931a) New Discoveries Relating to the Antiquity of Man, New York: Norton.

Keith, A (1931b) The Place of Prejudice in Modern Civilisation (Prejudice and Politics). London: Williams and Norgate.

Keith, A (1935) The ordeal of Ernst Haeckel, Rationalist Ann. pp. 3-12.

Keith, A (1946) Essays on Human Evolution. London Watts.

Keith, A (1950) An Autobiography. London: Watts.

Kennedy, GE (1980) Paleoanthropology. New York: McGraw.Hill.

Klaatsch, H (1910) Die Aurignac-Rasse und ihre Stellung im Stammbau der Menschheit. Z. Ethnol. 42:513-577.

Leakey, LSB (1965) The chapter of man unfolds. In: World Book Year Book. Chicago: Field Enterprises Educational Corp, pp. 107-122.

Leakey, LSB, and Goodall, VM (1969) Unveiling Man's Origins: Ten Decades of Thought on Human Evolution. Cambridge, Mass: Schenkman.

Leakey, LSB, Tobias, PV, and Napier, JR (1964) A new species of the genus Homo from Olduvai Gorge. Nature 202:7-9.

Leakey, RE, and Lewin, R (1977) Origins: What New Discoveries Reveal About the Emergence of Our Species and Its Possible Future. New York: Dutton.

Lévi-Strauss, C (1962) La Pensee Sauvage. Paris: Librairie Plon.

Litchfield, H (ed) (1915) Emma Darwin; A Century of Family Letters, 1792-1896. 2 vols. New York:Appleton.

Lovejoy, AO (1936) The Great Chain of Being: A Study of the History of an Idea. Cambridge, Mass: Harvard Univ. Press.

Lyell, C (1863) The Geological Evidences of the Antiquity of Man. London:John Murray.

Mayr, E (1974) Cladistic analysis or cladistic classification? Z. Zoolog. Systematiku. Evol.12:94-128.

Merton, RK (1938) Science, technology and society in seventeenth century England. Osiris 4:360-632.

O'Connell, MR (1969) The Oxford Cospirators: A History of the Oxford movement, 1833-1845. London: Macmillan.

Olson, R (1975) Scottish Philosophy and British Physics, 1750-1880: A Study in the Foundation of Victorian Scientific Style. Princeton, NJ: Princeton Univ, Press.

Osborn, HF (1894) From the Greeks to Darwin: An Outline of the Development of the Evolution Idea. New York: Charles Scribner's Sons.

Paley, W (1802) Natural Theology, or Evidences of the Existence and Attributes of the Deity Collected From the Appearances of Nature. London: Wilks and Taylor.

Rightmire, GP (1978) Florisbad and human population succession in southern Africa. Am. J. Phys. Anthropol. 48:475-486.

Robbins, LH (1972) Archeology in the Turkana district, Kenya. Science 176:359-366. 
Santa Luca, AP (1978) A reexamination of presumed Neandertal-like fossils. J. Hum. Evol. 7:619-636.

Schiller, F (1979) Paul Broca: Founder of French Anthropology, Explorer of the Brain. Berkeley: Univ. of California Press.

Schmidt, A (1962) Der Begriff der Natur in der Lehre von Marx. Frankfurt: Europaische Verlaganstatt.

Schwalbe, G (1901) Der Neanderthalschädel. Bonner Jahrbücher 106:1-72.

Schwalbe, G (1944) Studien zur Vorgeschichte des Menschen. Stuttgart: Schweizerbartsche Verlagsbuchandlung.

Simpson, GG (1944) Tempo and Mode in Evolution. New York: Columbia Univ. Press.

Simpson, GG (1953) The Major Features of Evolution. New York: Columbia Univ. Press.

Simpson, GG (1961) Principles of Animal Taxonomy. New York: Columbia Univ. Press.

Smith, FH, and Ranyard, GC (1980) Evolution of the supraorbital region in Upper Pleistocene fossil hominids from south-central Europe. Am. J. Phys. Anthropol. 53:589-610.

Snow, CP (1963) The Two Cultures: And a Second Look. 2nd ed. New York: Mentor Books.

Sollas, WJ (1908) On the cranial and facial characters of the Neanderthal race. Philos. Trans. R. Soc. Lond. (Bio). 199:281-339.

Spencer, F (1979) Aleš Hrdlička, M.D., 1869-1943: A Chronicle of the Life and Work of an American Physical Anthropologist. Ph.D. Dissertation, Anthropology. University of Michigan: Ann Arbor.

Stanley, SM (1979) Macroevolution: Pattern and Process. San Francisco: Freeman.

Stebbins, RE (1974) France. In TF Glick (ed): The Comparative Reception of Darwinism. Austin: Univ. of Texas Press, pp. 117-163.

Tattersall, I, and Eldredge, N (1977) Fact, theory, and fantasy in human paleontology. Am. Sci 65:204-211.

Teilhard de Chardin, $\mathrm{P}(1955)$ Le Phénomène Humain. Paris: Editions du Seuil.

Thoma, A (1973) New evidence for the polycentric evolution of Homo sapiens. J. Hum. Evol. 2:529-536.

Thoma, A (1975) Were the Spy fossils evolutionary intermediates between classic Neandertal and modern man? J. Hum. Evol. 4:387-410.

Topinard, P (1888) Review of Les-Ancêtres de nos Animaux dans les Temps Géologiques by Gaudry, A. Revue d'Anthropologie $3^{e}$ sér 3:472-474.

Trinkaus, E (1976) The evolution of the hominid femoral diaphysis during the Upper Pleistocene in Europe and the
Near East. Z. Morphol. Anthropol 67:291-319.

Trinkaus, $E$ (1977) A functional interpretation of the axillary border of the Neandertal scapula. J. Hum. Evol. 6:231-234.

Turner, CG II (1979) Dental anthropological indications of agriculture among the Jomon people of central Japan. Am. J. Phys. Anthropol. 51:619-636.

Vallois, HV (1952) Monophyletism and polyphyletism in man. S. Afr. J. Sci. 49:69-79.

Van Valen, L (1978) Why not to be a cladist. Evol. Theory 3:285-299.

Virchow, $\mathbf{R}$ (1877) Die Freiheit der Wissenschaft in Modernen Staat. Berlin: Weigandt, Hempel and Parey.

Virchow, R (1895) Pithecanthropus erectus Dubois. Z Ethnol. 27:336-337, 435-440, 648-656, 723, 744-747, $787-793$.

Vrba, ES (1980) Evolution, species and fossils: How does life evolve? S. Afr. J. Sci. 76:61-84.

Weatherby, HL (1973) Cardinal Newman in His Age: His Place in English Theology and Literature. Nashville, Tenn: Vanderbilt Univ. Press.

Wegner, RN (1910) A new theory of the descent of man. Nature 85:119-121.

Weidenreich, F (1928) Entwicklungs - und Rassentypen des Homo primigenius. Natur und Volk 58:1-13, 51-62.

Weidenreich, F (1943a) The "Neanderthal Man" and the ancestors of "Homo sapiens." Am. Anthropol. 45:39-48.

Weidenreich, F (1943b) The skull of "Sinanthropus pekinensis": A comparative study on a primitive hominid skull. Palaeontologia Sinica New Series D. 10:1-484.

Weidenreich, F (1946a) Apes, Giants and Man. Chicago: Univ. of Chicago Press.

Weidenreich, F (1946b) Generic, specific and subspecific characters in human evolution. Am. J. Phys. Anthropol. 4:413-431,

Weidenreich, F (1947) Facts and speculations concerning the origin of Homo sapiens. Am. Anthropol. 49:187-203.

Weinert, H (1947) Menschen der Vorzeit 2nd ed. Stuttgart: F. Enke.

Wendt, H (1956) In Search of Adam. Boston: Houghton Mifflin.

Wilberforce, $S(1860)$ Review of On the Origin of Species by Darwin, C. The Quarterly Review 108:118-138.

Wilson, LG (ed) (1970) Sir Charles Lyell's Scientific Journals on the Species Question. New Haven: Yale Univ. Press.

Wilson, LG (1972) Charles Lyell: The Years to 1841: The Revolution in Geology. New Haven: Yale Univ. Press.

Wolpoff, MH (in press) Cranial capacity estimates for Olduvai hominid 7. Am. J. Phys. Anthropol. 